\title{
HUBUNGAN FAKTOR-FAKTOR TREATMENT DELAY DENGAN KASUS KANKER PAYUDARA STADIUM LANJUT DI RSUD ABDUL WAHAB SJAHRANIE SAMARINDA TAHUN 2019 RELATIONSHIP BETWEEN TREATMENT DELAY FACTORS WITH ADVANCED STAGE OF BREAST CANCER CASES AT RSUD ABDUL WAHAB SYAHRANIE SAMARINDA 2019
} Safira Dhia Rahmawaty ${ }^{(1)}$, Zainal Abidin ${ }^{(2)}$, Swandari Paramita ${ }^{(3)}$

Program Studi Pendidikan Dokter, Fakultas Kedokteran Universitas Mulawarman ${ }^{(1)}$, Laboratorium Ilmu Bedah, Fakultas Kedokteran ${ }^{(2)}$, Universitas Mulawarman, Laboratorium Ilmu Kesehatan Masyarakat, Fakultas Kedokteran Universitas Mulawarman ${ }^{(3)}$ E-mail: safiradhia97@gmail.com ${ }^{(1)}$, zainalabidin@gmail.com ${ }^{(2)}$, swandariparamita@gmail.com ${ }^{(3)}$

\begin{abstract}
Abstrak: Kanker payudara stadium lanjut dapat terjadi disebabkan adanya keterlambatan berobat penderitanya. Keterlambatan berobat dapat terjadi oleh karena penderita kanker payudara tidak menyadari tanda dan gejala kanker payudara serta mengalami rasa takut berobat, tidak mau berobat dan menggunakan pengobatan non medis. Penelitian ini bertujuan untuk mengetahui hubungan kanker payudara stadium lanjut dengan faktor takut berobat karena takut terdiagnosa kanker dan takut pengobatan; faktor tidak mau mendapat efek samping pengobatan; faktor penggunaan pengobatan non medis sebelumnya berupa pengobatan alternatif. Penelitian ini merupakan jenis penelitian observasional analitik dengan metode cross sectional. Responden penelitian merupakan penderita kanker payudara stadium lanjut di RSUD Abdul Wahab Sjahranie dengan menggunakan simple sampling dan uji statistik chi-square dengan jumlah 97 responden. Hasil penelitian terdapat hubungan antara faktor takut terdiagnosa $\mathrm{p}=0,00, \mathrm{p}=0,00, \mathrm{p}=0,03$, dan $\mathrm{p}=0,01$ dimana $(p<0,05)$ dengan pengetahuan penderita kanker payudara mengenai benjolan yang dirasakan.
\end{abstract}

Kata Kunci : Kanker Payudara, Stadium Lanjut, Takut Berobat, Tidak Mau Berobat, Pengobatan Non Medis

Abstract: Advanced stage of breast cancer can occur due to the late treatment of sufferers. Delay in treatment can occur because breast cancer sufferers are not aware of the signs and symptoms of breast cancer and experience a fear of treatment, do not want to seek treatment and use non-medical treatment. This study aims to determine the relationship the advanced stage of breast cancer with treatment fear factors because of fear of diagnosed breast cancer and fear of cancer treatment; factors that do not want to seek treatment because they do not want to have side effects of treatment; the previous use of non-medical treatment factor in the form of alternative medicine. This research is an observational analytic study with cross sectional method. Respondents of the study were patients with advanced stage of breast cancer at RSUD Abdul Wahab Sjahranie using simple sampling and chisquare statistical tests with 97 respondents. The results of the study showed a relationship between fear factor for cell growth $p=0.00, p=0.00, p=0.03$, and $p=0.01$ while $(p<0,05)$ with knowledge of breast cancer sufferers regarding the perceived lump.

Keywords: Breast Cancer, Advanced Stage, Fear of Treatment, Do Not Want to Seek Treatment, NonMedical Treatment 


\section{PENDAHULUAN}

Kanker payudara adalah suatu penyakit yang menyerang payudara yang meliputi kulit, puting, areola dan isi payudara tersebut. Kanker ini menyerang sel-sel dan jaringan payudara sehingga mengalami peningkatan pertumbuhan yang tidak normal dan berlangsung cepat, menginfiltrasi jaringan sekitar bahkan dapat menyebar jauh ke bagian tubuh lain. Angka kejadian kanker payudara ini mengalami peningkatan dari tahun ke tahun diikuti peningkatan angka kematian diseluruh belahan dunia maupun di Indonesia. Kanker payudara umumnya terjadi pada wanita. Namun pada beberapa kasus kanker payudara juga dapat terjadi pada pria (Komite Penanggulangan Kanker Nasional [KPKN], 2013). Kanker payudara dapat terjadi pada pria dengan riwayat penyakit gynecomasti sebelumnya. Kejadian penderita kanker payudara pada pria tidak banyak hanya sekitar 1 dari 100.000 atau sekitar $<1 \%$ pria di seluruh dunia (Silvestri, dkk., 2016).

Kanker payudara masih menjadi salah satu penyakit mematikan. Insiden kanker payudara meningkat dari 12,7 juta kasus pada tahun 2008 menjadi 14,1 juta kasus pada tahun 2012 dengan jumlah kematian meningkat dari 7,6 juta kasus pada tahun 2008 menjadi 8,2 juta kasus pada tahun 2012 di dunia menurut data World Health Organization (WHO) tahun 2013. Data yang dilaporkan pada kasus kanker payudara meningkat dari 221 kasus pada tahun 2003 menjadi 657 kasus pada tahun 2008 di Rumah Sakit Kanker Dharmais Jakarta pada tahun 2014. Berdasarkan hasil riset GLOBOCAN, International Agency for Research on Cancer (IARC) tahun 2018 diketahui terdapat 2.088.849 kasus baru kanker payudara pertahun di seluruh dunia dan $6,6 \%$ kasus kematian yang disebabkan oleh kanker payudara di seluruh dunia. Menurut data yang didapatkan dari National Cancer Institute's Surveillance, Epidemiologi and End Result Program [NCI] tahun 2018, perkiraan kasus baru kanker payudara di Amerika sekitar $15.3 \%$ dari semua jenis kasus baru kanker. Berdasarkan data Kementerian Kesehatan Republik Indonesia (Kemenkes RI) tahun 2013, jumlah kasus kanker payudara sebanyak 61.682 kasus dilaporkan di Kalimantan Timur dan jumlah kasus kanker payudara sebanyak 1879 kasus di Kota Samarinda. Kejadian kanker payudara dilaporkan sebagai penyebab kematian tertinggi kedua di dunia.

Kanker payudara memiliki angka mortalitas dan morbiditas yang tinggi baik di dunia maupun di Indonesia. Selain itu, kecenderungan meningkat nya kasus ini membuat kanker payudara sebagai suatu masalah kesehatan yang penting bagi wanita. Angka insiden yang cukup tinggi didapatkan di negara negara maju maupun berkembang. Kecenderungan pasien kanker payudara yang datang ke dokter atau ke rumah sakit di negara berkembang terdiagnosis pada stadium lanjut (Benjamin, dkk., 2008). Hal ini terjadi karena banyak pasien wanita di negara berkembang tidak menyadari tanda dan gejala kanker serta kurang mengetahui bagaimana deteksi kanker diakibatkan masih kurang nya edukasi pengetahuan tentang kanker di masyarakat. Pengetahuan akan kanker payudara sangat diperlukan bagi masyarakat luas sehingga dapat membantu masyarakat mengenali kanker payudara yang pada akhirnya penderita dapat terdeteksi dan terdiagnosis dini. Kanker payudara dapat dikenali dari tanda dan gejala yang ditimbulkannya. Penanganan kanker payudara yang datang pada stadium dini akan memberikan hasil akhir berupa prognosis yang baik dan pada pasien yang terdiagnosis stadium lanjut biasanya tidak banyak terapi yang mempengaruhi keberhasilan terapi atau prognosis semakin kecil pada survival kanker (NC, 1993). Menurut NCI tahun 2018 hanya sekitar 6\% wanita yang mengalami kanker payudara stadium lanjut yang dapat survive selama 5 tahun bahkan lebih. Pasien kanker payudara yang datang pada stadium lanjut atau stadium menyebar memiliki tujuan terapi yang diberikan bersifat paliatif (Ramli, 2017). Terapi paliatif digunakan hanya untuk mengurangi keluhan yang ditimbulkan, mencegah penyakit berlanjut dan menyebar, memperbaiki kualitas hidup dan akhirnya menambah usia harapan hidup pasien. 
Berdasarkan data WHO tahun 2012 diperkirakan lebih $50 \%$ penderita kanker payudara di Indonesia datang memeriksakan penyakit kanker yang dideritanya sudah pada stadium lanjut dimana sudah terjadi kelainan seperti adanya borok di payudara atau menyerupai kulit jeruk, ukuran tumor yang besar dan di dapatkan tanda tanda penyebaran dari kanker payudara tersebut. Pasien akan datang dengan keluhan nyeri namun terkadang disertai dengan lengan setempat yang membesar. Keluhan berupa nyeri pada payudara yang membuat penderita kanker payudara datang untuk memeriksakan penyakitnya (Panigoro, 2017).

Pada negara berkembang termasuk di Indonesia, keterlambatan pengenalan dan diagnosis kanker payudara disebabkan beberapa faktor yaitu keterlambatan pasien (patient delay), keterlambatan dalam sistem kesehatan (referral delay) dan keterlambatan dalam mendapat perawatan (treatment delay). Keterlambatan pasien dimana jarak waktu pertama konsultasi diatas 3 bulan. Hal ini disebabkan kurang nya kesadaran diri untuk deteksi dini, adanya faktor budaya hingga yang paling sering yaitu ketakutan akan diagnosa kanker yaitu penderita takut untuk berkonsultasi walaupun sudah merasakan gejala (Jaye, et al., 2011). Keterlambatan dalam sistem kesehatan dimana pasien datang lebih dari 4 minggu dari tempat konsultasi pertama. Keadaan ini disebabkan kurangnya pengetahuan tenaga kesehatan mengenai penanganan kanker yang benar dilihat dari sistem rujukan (NM, 2006). Keterlambatan dalam mendapat perawatan dimana waktu diagnosis ditegakkan hingga tindakan dilakukan lebih dari 4 minggu. Hal ini terjadi apabila pasien memerlukan waktu berpikir untuk menerima saran (Afzelius, dkk., 1994). Penderita menolak tindakan medis dan pergi ke pengobatan alternatif dan saat stadium lanjut kembali ke terapi medis. Penelitian yang dilakukan oleh Ario, Jacobus, Novina dan Intan (2013) di Surabaya menjelaskan adanya hubungan faktor usia dan faktor pendidikan dengan keterlambatan pengobatan. Namun faktor psikologi dari berbagai usia dan tingkat pendidikan berperan menentukan pasien berkonsultasi serta berhubungan dengan keterlambatan ditangani pasien.

Meningkatnya angka kejadian kanker payudara yang datang pada stadium lanjut dimana masih kurangnya tingkat kesadaran, pengetahuan, rasa takut tentang terjadinya kanker payudara disertai kurangnya data di Indonesia khususnya di Samarinda, Kalimantan Timur. Oleh karena itu, peneliti ingin melihat hubungan antara keterlambatan datang pasien kanker payudara yang di RSUD Abdul Wahab Sjahranie Samarinda dengan melihat faktor-faktor yang menyebabkan mereka terlambat untuk memeriksakan diri ke dokter atau ke Rumah sakit.

\section{METODE PENELITIAN}

Penelitian ini merupakan penelitian observasional analitik dengan pendekatan cross-sectional. Penelitian dilakukan di Rumah Sakit Umum Daerah (RSUD) Abdul Wahab Sjahranie Samarinda pada bulan akhir bulan April hingga pertengahan bulan Mei. Populasi dalam penelitian ini adalah seluruh pasien kanker payudara stadium lanjut di poliklinik bedah onkologi dan ruang kemoterapi yang dibuktikan secara klinis dan patologi anatomi yang datang berobat dari bulan Januari 2019 di RSUD Abdul Wahab Syahranie Samarinda. Sampel berjumlah minimal 97 responden yang diperoleh berdasarkan perhitungan peneliti. Teknik pengambilan sampel dari populasi dengan teknik simple random sampling dengan inklusi kriteria yaitu penderita kanker payudara stadium lanjut yang telah di buktikan secara klinis dan patologi, penderita kanker payudara stadium lanjut terbaru dan residif, penderita kanker payudara stadium lanjut yang tidak di ikuti malignanancy lainnya. penderita kanker payudara stadium lanjut bersedia ikut penelitian. Instrumen yang digunakan dalam penelitian ini adalah rekam medis dan wawancara untuk mencari tahu alasan penyebab keterlambatan berobat penderita kanker payudara stadium lanjut di RSUD Abdul Wahab Syahrani Samarinda. Analisis data dilakukan menggunakan 
analisis univariat yaitu mendeskripsikan sebaran data pada masing-masing variabel bebas dan variabel terikat. Pada penelitian ini, peneliti menggunakan uji komparatif chisquare untuk mencari hubungan yang bermakna

\section{HASIL}

Tabel 1. Karakteristik Pasien Kanker Payudara Stadium Lanjut

\begin{tabular}{|c|c|c|c|}
\hline Karakteristik & Kategori & $\begin{array}{l}\text { Frekuensi } \\
\text { (n) }\end{array}$ & $\begin{array}{c}\text { Persentase } \\
(\%)\end{array}$ \\
\hline \multirow{7}{*}{ Usia } & $20-29$ & 3 & $3,01 \%$ \\
\hline & $30-39$ & 4 & $4,12 \%$ \\
\hline & $40-49$ & 34 & $35,06 \%$ \\
\hline & $50-59$ & 33 & $34,02 \%$ \\
\hline & $60-69$ & 16 & $16,50 \%$ \\
\hline & $70-79$ & 5 & $5,15 \%$ \\
\hline & $80-89$ & 2 & $2,06 \%$ \\
\hline \multirow{3}{*}{ Pekerjaan } & IRT & 79 & $81,4 \%$ \\
\hline & PNS & 9 & $9,3 \%$ \\
\hline & Swasta & 9 & $9,3 \%$ \\
\hline \multirow[b]{2}{*}{ Status Penikahan } & Menikah & 95 & $97,93 \%$ \\
\hline & $\begin{array}{l}\text { Tidak } \\
\text { Menikah }\end{array}$ & 2 & $2,06 \%$ \\
\hline \multirow{4}{*}{$\begin{array}{c}\text { Pemeriksaan } \\
\text { Imunohistokimia }\end{array}$} & Her $2+$ & 8 & $53,3 \%$ \\
\hline & ER & 7 & $46,7 \%$ \\
\hline & $\mathrm{Ki}-67$ & 9 & $60 \%$ \\
\hline & PR & 8 & $53,3 \%$ \\
\hline \multirow{2}{*}{$\begin{array}{l}\text { Pengetahuan } \\
\text { Penderita }\end{array}$} & Tahu & 66 & $68,04 \%$ \\
\hline & $\begin{array}{l}\text { Tidak } \\
\text { Tahu }\end{array}$ & 31 & $31,95 \%$ \\
\hline Takut & Ya & 64 & $65,9 \%$ \\
\hline $\begin{array}{l}\text { Terdiagnosa } \\
\text { Kanker }\end{array}$ & Tidak & 33 & $\%^{34,02}$ \\
\hline Takut Biaya & Ya & 30 & $30,9 \%$ \\
\hline Pengobatan & Tidak & 67 & $69,07 \%$ \\
\hline Tidak Mau & Ya & 46 & $47,4 \%$ \\
\hline Terkena Efek & Tidak & 51 & $52,5 \%$ \\
\hline \multirow{2}{*}{$\begin{array}{c}\begin{array}{c}\text { Pengobatan Non } \\
\text { Medis }\end{array} \\
\end{array}$} & Ya & 53 & $56,45 \%$ \\
\hline & Tidak & 44 & $45,3 \%$ \\
\hline
\end{tabular}

Penelitian ini dilakukan selama bulan akhir bulan April 2019 hingga pertengahan bulan Mei 2019 untuk mengetahui hubungan faktor- faktor treatment delay dengan kasus kanker payudara stadium lanjut di RSUD Abdul Wahab Sjahranie Samarinda Tahun 2019.

Tabel 2 Analisis Hubungan Faktor - Faktor Treatment Delay Dengan Kasus Kanker Payudara Stadium Lanjut

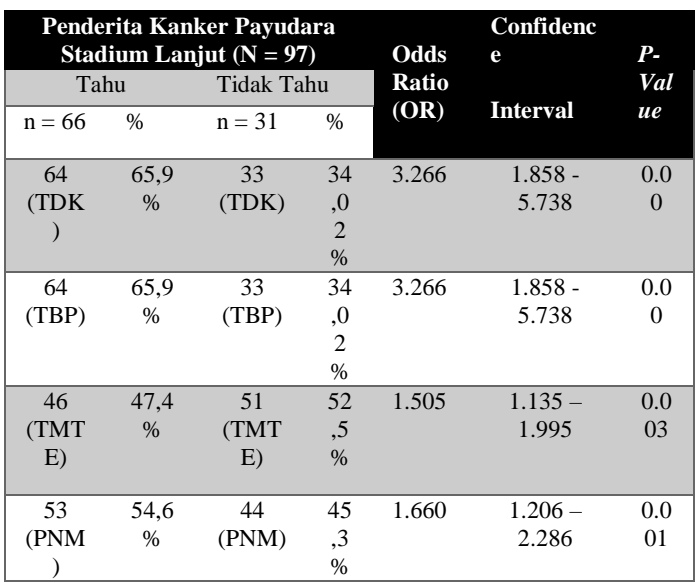

Hasil analisis menggunakan uji chi square mengenai faktor takut akan diagnosa kanker dengan hasil $0,00 \quad(\mathrm{p}<0,05)$ yang diartikan secara statistik ada hubungan yang bermakna antara antara faktor takut terdiagnosa kanker dengan kejadian kanker payudara stadium lanjut baik yang mengetahui gejala dan tanda maupun yang tidak mengetahui. Pada faktor takut pengobatan kanker payudara memiliki hasil $0,00(\mathrm{p}<0,05)$ yang diartikan secara statistik ada hubungan yang bermakna antara faktor takut akan pengobatan kanker dengan kejadian kanker payudara stadium lanjut baik yang mengetahui gejala dan tanda maupun yang tidak mengetahui. Pada faktor tidak mau terkena efek samping dari pengobatan kanker payudara memiliki hasil 0,03 $(\mathrm{p}<0,05)$ yang diartikan secara statistik ada hubungan yang bermakna antara faktor tidak mau terkena efek samping dari pengobatan kanker payudara dengan kejadian kanker payudara stadium lanjut baik yang mengetahui gejala dan tanda maupun yang tidak mengetahui. Pada faktor pengobatan non medis berupa penggunaan obat alternatif memiliki hasil $0,01(\mathrm{p}<0,05)$ yang diartikan secara statistik ada hubungan yang bermakna antara penderita kanker payudara yang menggunakan obat alternatif sebelumnya dengan kejadian kanker payudara stadium lanjut baik yang mengetahui gejala dan tanda maupun yang tidak mengetahui.

\section{DISKUSI}


Pada penelitian yang dilakukan pada 97 responden ditemukan penderita kanker payudara stadium lanjut pada usia 40-49 tahun tediri atas 34 responden $(35,06 \%)$, usia 50-59 tahun terdiri atas 33 responden (34,02 $\%)$. Penderita kanker payudara stadium lanjut banyak ditemukan pada usia dekade 40 hingga dekade 60 tahun (Howlader, dkk., 2016). Pada usia dekade 40 hingga dekade 60 menurut penelitian cenderung meningkat penderita kanker payudara biasanya disertai beberapa faktor yang mendukung seperti gaya hidup penderita yang mempengaruhi IMT lebih dari batas normal (Nelson, dkk., 2012). Kemudian pengaruh hormonal dimana penderita kanker payudara yang menarche pada usia dini namun menikah dan memiliki keturunan pada usia tua dan juga penderita kanker payudara yang menggunakan terapi hormonal untuk mencegah memiliki keturunan dapat menyebabkan pengaruh hormon esterogen dan progesteron selalu terpapar sehingga mempengaruhi peningkatan proliferasi epitel duktal payudara dan payudara tidak mengalami differensiasi (Anothaisintawee, dkk., 2013). Selain itu, pengaruh berdasarkan faktor keturunan dapat mempengaruhi resiko terkena kanker payudara. Hal tersebut dapat berdampak pada mutasi gen dan bersifat karsinogenesis (Purwanto, dkk., 2014). Sehingga usia penderita kanker payudara banyak ditemukan pada dekade 40 an hingga dekade 60 an yang disertai pengaruh IMT, pengaruh hormonal baik dari faktor eksternal berupa pola hidup maupun faktor internal berupa keturunan dari keluarga secara garis langsung. Pemeriksaan kanker payudara dapat dilakukan dengan pemeriksaan fisik. Selain itu, pemeriksaan kanker payudara dapat dilakukan dengan pemeriksaan penunjang berupa USG dan MRI namun dapat dilakukan dengan pemeriksaan imunohistokimia. Akan tetapi, menurut penelitian yang dilakukan Manuaba dan Wijaya pada tahun 2016 mengatakan pemeriksaan imunohistokimia tidak terlalu berpengaruh dengan status usia pasien kanker payudara. Peneliti hanya menemukan 15 data responden dari 97 responden yang diteliti disebabkan masih lebih banyak pemeriksaan dengan mengunakan sitologi dengan cara biopsi maupun FNAB (Fine Needle Aspiration Biopsy).

Hasil pengolahan data pada kanker payudara stadium lanjut yang takut terdiagnosa kanker menggunakan statistik pola hubungan uji analisis chi-square dengan hasil nilai signifikansi sebesar $0,00(\mathrm{p}<0,05)$. Hal ini menunjukan benar adanya hipotesis yang mengatakan hubungan antara keterlambatan berobat pada penderita kanker payudara stadium lanjut dengan pasien takut terdiagnosa kanker. Hasil penelitian didukung dengan adanya penelitian yang dilakukan di Saaland German pada tahun 2008 yang mengatakan terdapat hubungan keterlambatan dalam berobat pada penderita kanker payudara stadium lanjut yang disebabkan takut terdiagnosa kanker berupa takut dengan pertumbuhan benjolan dengan pesat. Penelitian mengungkapkan angka penderita kanker payudara berkunjung ke dokter sebanyak 17,4\% berkunjung lebih dari 3 bulan sejak keluhan muncul dan lebih dari setengah atau sekitar $55 \%$ berkunjung dibulan ke 2 karena rasa takut akan kanker payudara. Selain itu, penelitian Slaoui, dkk., (2014) memperkuat dengan memberikan fakta adanya hubungan keterlambatan dalam berobat pada kanker payudara stadium lanjut dengan faktor takut terdiagnosa kanker pada wanita lanjut usia.

Hasil pengolahan data pada penderita kanker payudara stadium lanjut yang takut dengan pengobatan kanker payudara seperti operasi, kemoterapi dan radiasi menggunakan statistik pola hubungan uji analisis chi-square dengan hasil signifikansi sebesar $0,00 \quad(p<0,05)$. Hal menunjukan benar adanya hipotesis yang mengatakan hubungan antara keterlambatan berobat pada penderita kanker payudara stadium lanjut dengan takut pengobatan kanker. Hasil penelitian didukung dengan penelitian yang mengatakan bahwa penderita kanker payudara tidak ingin berobat disebabkan takut dengan terapi kanker payudara berupa operasi, kemoterapi maupun radiasi (Hikmanti \& Adriani, 2016). Selain itu, hal ini diperkuat dengan keterbatasan pengetahuan akan pentingnya penangan dini 
pada kanker payudara untuk mengurangi progresifitas sel kanker (Dyanti \& Suariyani, 2016).

Hasil pengolahan data pada penderita kanker payudara stadium lanjut yang tidak mau terkena efek samping dari pengobatan kanker payudara menunjukan statistik pola hubungan uji analisis chi-square dengan hasil signifikansi sebesar 0,03 $(p<0,05)$. Hal menunjukan benar adanya hipotesis yang mengatakan hubungan antara keterlambatan berobat pada penderita kanker payudara stadium lanjut yang tidak mau terkena efek samping dari pengobatan kanker payudara. Hasil penelitian ini berkaitan dengan penelitian yang dilakukan Stu rrme, Stegmaier, Ziegler, Dhom dan Arndt pada tahun 2002 yang mengatakan bahwa banyak penderita kanker payudara yang tidak mau berobat karena tidak ingin mendapatkan efek samping dari terapi pengobatan kanker payudara berupa kecacatan atau ada yang hilang akibat terapi yang dilakukan pada penderita kanker payudara. Efek samping yang dimaksud seperti hilangnya bentukan payudara akibat operasi mastektomi hingga adanya reaksi anafilaktik, mual, muntah, lemas, hilang nafsu makan, rambut rontok hingga kulit semakin kusam akibat kemoterapi dan radiasi (Suyatno \& Pasaribu, 2014).

Hasil pengolahan data penderita kanker payudara stadium lanjut yang menggunakan pengobatan alternatif menunjukan statistik pola hubungan uji analisis chi-square dengan signifikansi sebesar 0,01 $(\mathrm{p}<0,05)$. Hal ini menunjukan benar adanya hipotesis yang mengatakan hubungan keterlambatan berobat pada penderita kanker payudara stadium lanjut dengan penggunaan obat alternatif. Hasil sesuai dengan penelitian Hikmanti dan Adriani pada tahun 2016 dimana penggunaan obat alternatif dapat menimbulkan efek samping hingga komplikasi pada pengobatan alternatif yang digunakan dan menambah progresifitas kanker. Namun, pengobatan alternatif ini banyak digunakan karena dapat mengurangi keluhan berupa gejala suatu penyakit tetapi tidak menyembuhkan. Selain itu, penyebab banyaknya penggunaan obat alternatif disebabkan lebih banyak promosi produk mereka dengan menganggap lebih mudah, tidak menggangu dan dianggap terjangkau secara ekonomis yang dapat membuat penderita kanker payudara tertarik dibanding tenaga medis yang gencar melakukan edukasi untuk deteksi dini kanker payudara (Dyanti \& Suariyani, 2016). Padahal dengan mengulur waktu untuk memeriksakan diri ke tenaga medis dan ditangani dengan cepat akan meningkatkan progresifitas dari sel kanker tanpa penderita tersebut menyadari (Mambodiyanto \& Maharani, 2016).

\section{KESIMPULAN}

Berdasarkan hasil penelitian dan pembahasan yang telah diuraikan peneliti menyimpulkan bahwa :

Pertama, pada penelitian penderita kanker payudara stadium lanjut yang takut terdiagnosa kanker payudara terdapat adanya hubungan yang bermakna disebabkan penderita takut akan pertumbuhan benjolan yang pesat dan adanya nyeri yang dirasakan. Kedua, pada penelitian penderita kanker payudara stadium lanjut yang takut akan pengobatan kanker payudara terdapat adanya hubungan yang bermakna disebabkan penderita takut pengobatan kanker payudara berupa operasi, kemoterapi dan radiasi. Ketiga pada penelitian penderita kanker payudara stadium lanjut yang tidak mau mendapat efek samping dari pengobatan kanker payudara terdapat adanya hubungan yang bermakna disebabkan tidak mau kehilangan bentukan payudara akibat operasi mastektomi hingga adanya reaksi anafilaktik, mual, muntah, lemas, hilang nafsu makan, rambut rontok hingga kulit semakin kusam akibat kemoterapi dan radiasi. Keempat, pada penelitian penderita kanker payudara stadium lanjut yang menggunakan obat alternatif alternatif sebelumnya terdapat adanya hubungan yang bermakna disebabkan pengaruh pemakaian obat alternatif lebih gencar usaha promotif dan dirasa mudah, nyaman, cepat dan murah sehingga banyak penderita lebih tertarik ke pengobatan 
alternatif terlebih dahulu tanpa memikirkan dampak efek samping dari penggunaanya.

Berdasarkan hasil penelitian dan pembahasan yang telah diuraikan peneliti menyarankan bahwa: Pertama, perlu diberikan edukasi kepada wanita bahkan pria mengenai faktor resiko kanker payudara berupa gejala dan tanda kanker payudara serta bahaya akan progresifitas kanker payudara sehingga mempengaruhi pemikirian masyarakat yang merasa memiliki faktor resiko agar deteksi dini segera dan yang tidak memiliki faktor resiko agar menghindari penyebab kanker payudara tersebut. Kedua, perlu ditingkatkan kembali pada data rekam medis agar lebih ditata dengan baik dalam hal pencatatan data penderita mulai dari tanda gejala yang terlihat maupun tidak terlihat serta pengobatan yang telah dilalui agar hasil dapat lebih valid.

\section{DAFTAR PUSTAKA}

Afzelius, P., Zedeler, K., Sommer, H., Mouridsen, H., \& Blichert, T. (1994). Patient's and Doctor's Delay In Primary Breast Cancer. Prognostic Implications, 33, 345-51.

Anothaisintawee, T., Wiratkapun, C., Lerdsitthichai, P., Kasamesup, V., Wongwaisayawan, S., \& Srinakarin, J. (2013). Risk Factor Breast Cancer: A Systematic Review and Meta Analysis (Vol. 25). Asia Pacific J Public Heatlh.

Benjamin, A. O., Yip, C., Smith, R., Shyyan, R., Sener, S., Eniu, A., . . . Harford, J. (2008). Guideline Implementation for Breast Healthcare in Low-Income and Middle-Income Countries: Overview of The Breast Health Global Initiative Global Summit 2007. 15, 113.

Global Cancer Statistic (2018): GLOBOCAN Estimates of Incidence and Mortality Worldwide for 36 Cancer in 185 Countries. France : International Agency for Reasearch on Cancer.

Djatmiko, A., Octavianus, J., Fortunata, N., \& Intan, A. (2013). Profil Cancer Delay pada Kasus Kanker Payudara di Rumah Sakit Onkologi Surabaya. Indonesian Journal of Cancer, 7(2), 47-52.

Dyanti, G. R., \& Suariyani, N. P. (2016). Faktor-Faktor Keterlambatan Penderita Kanker Payudara Dalam Melakukan Pemeriksaan Awal Ke Pelayanan Kesehatan. Denpasar: Program Studi Kesehatan Masyarakat Fakultas Kedokteran Universitas Udayana.

Hikmanti, A., \& Adriani, F. N. (2016). Analisis Faktor-Faktor Yang Mempengaruhi Keterlambatan Pengobatan Pada Wanita Penderita Kanker Payudara. Purwekerto: STIKES Harapan Bangsa.

Howlader, N., Noone, A., Krapcho, M., Miller, D., Bishop, K., \& Altekruse, S. (2016). Breast Cancer Fact and Figures. USA: National Cancer Insitute.

Jaye, S. M., Mullan, P. B., Subhojit, D., Hablas, A., Gaafar, R., Seifeldin, I. A., Soliman, A. (2011). PatientMediated Factors Predicting Early and Late Stage Presentation of Breast Cancer in Egypt (Vol 20), 532-537.

KEMENKES RI. (2015) Panduan Penatalaksanaan Kanker Payudara. Jakarta: KEMENKES RI.

Kementerian Kesehatan Republik Indonesia. (2014). Hilangkan Mitos Kanker. Jakarta : Departemen Kesehatan Republik Indonesia. 
KPKN. (2014). Pedoman Nasional Pelayanan Kanker Payudara. Jakarta: Kementrian Kesehatan RI.

Komite Penanggulangan Kanker Nasional. (2016). Pedoman Nasional Pelayanan Kanker Payudara. Jakarta: Kementrian Kesehatan RI.

Mambodiyanto, \& Maharani, P. (2016). Pengaruh Pengobatan Alternatif Sebagai Faktor Penyebab Keterlambatan Penanganan Medis Penderita Kanker Payudara di Puskesmas Lumbir Kabupaten Banyumas. Purwokerto: Staf Pengajar Fakultas Kedokteran Universitas Muhammadiyah.

Nelson, H., Zakher, B., Cantor, A., Fu, R., Griffin, J., \& ES, O. (2012). Risk Factor for Woman aged 40 to 49 years: a systematic review and meta analysis. Ann Intern Med.

NM, S. (2006). Knowledge Gained After a Brief CME Module on Breast Cancer Diagnosis. 21, 169-74.

Nelson, H., Zakher, B., Cantor, A., Fu, R., Griffin, J., \& ES, O. (2012). Risk Factor for Woman aged 40 to 49 years: a systematic review and meta analysis. Ann Intern Med.

Panigoro, S. S. (2017). Menyelaraskan Idealisme dengan Kenyataan Penanganan Kanker Payudara di Indonesia;Manajemen Terkini Kanker Payudara (Vol. 1). (F. B. Sobri, Y. Azhar, I. G. Wibisana, Rachman, \& Abdul, Eds.) Jakarta: Media Aesculapius.

Ramli, M. (2017). Kanker Payudara dari Waktu ke Waktu;Manajemen Terkini Kanker Payudara (Vol. 1). (F. B. Sobri, Y. Azhar, I. G. Wibisana,
Rachman, \& Abdul, Eds.) Jakarta: Media Aesculapius.

Silvestri, V., Barrowdale, D., Mulligan, A. M., Neuhausen, S. L., Fox, S., Karlan, B. Y., . . . Thull, D. L. (2016). Male breast cancer in BRCA 1 and BRCA2 mutation carriers: pathology data from the Consortium of Investigators of Modifiers of BRCA1/2. Breast Cancer Res, 18.

Slaoui, M., Razine, R., Ibrahimi, A., Attaleb, M., Mzibri, M., \& Amrani, M. (2014). Breast Cancer in Morocco: A Literature Review. Morroco: Asian Pacific Journal of Cancer Prevention.

Stu r̈me, T., Stegmaier, C., Ziegler, H., Dhom, G., \& Arndt, V. (2002). Patient Delay and Stage of Diagnosis Among Breast Cancer Patients in Germany - A Population Based Study. UK: British Journal of Cancer.

Suyatno, \& Pasaribu, E. (2014). Bedah Onkologi Diagnosis dan Terapi (Vol. 2). (S. (. dr. Suyatno, Ed.) Jakarta: CV Sagung Seto. 